\title{
KEEFEKTIFAN MODEL PROBLEM BASED LEARNING UNTUK MENINGKATKAN HASIL BELAJAR IPA
}

\author{
Mariya \\ mariayaspd@yahoo.com \\ SD Negeri 015 Geringging Jaya, Kuantan Singingi, Indonesia
}

\begin{abstract}
This research was conducted at 015 Public Elementary School Geringging Jaya, Kuantan Singingi Regency. The subjects of this study were 18th grade $V$ students consisting of 8 male students and 10 female students. The purpose of this study is to improve student science learning outcomes by applying a problem based learning model. This research consists of planning, implementing, observing, and reflecting. The results showed, seen from the average value of a student's base score of 63.2 with 10 students completing as many as a percentage of $55.5 \%$ experienced an increase in the first cycle with an average value of students becoming 74.3 with students completing being 14 people with a percentage of $77.7 \%$. Whereas in the second cycle again menngkata with an average value of 86.7 with students who finished up to 16 people with a percentage of $88.8 \%$.Can the researchers conclude that the application of the problem based learning model is effective in improving the learning outcomes of science students in grade at 015 Public Elementary School Geringging Jaya.
\end{abstract}

Keywords: problem based learning model, science learning outcomes

\begin{abstract}
ABSTRAK
Penelitian ini dilaksanakan di SD Negeri 015 Geringging Jaya, Kabupaten Kuantan Singingi. Subjek penelitian ini adalah siswa kelas V yang berjumlah 18 orang yang terdiri dari 8 siswa laki-laki dan 10 siswa perempuan. Tujuan penelitian ini adalah meningkatkan hasil belajar IPA siswa dengan menerapkan model problem based learning. Penelitian ini terdiri dari perencanaan, pelaksanaan, pengamatan, dan refleksi. Hasil penelitian menunjukan, dilihat dari nilai rata-rata skor dasar siswa adalah 63.2 dengan siswa yang tuntas sebanyak 10 orang dengan persentase sebesar $55.5 \%$ mengalami peningkatan pada siklus I dengan nilai rata-rata siswa menjadi 74.3 dengan siswa yang tuntas menjadi 14 orang dengan persentase sebesar $77.7 \%$. Sedangkan pada siklus II kembali meningkatkan dengan nilai rata-rata sebesar 86.7 dengan siswa yang tuntas menjadi 16 orang dengan persentase sebesar $88.8 \%$. Dapat peneliti simpulkan bahwa penerapan model problem based learning efektif meningkatkan hasil belajar IPA siswa kelas V SD Negeri 015 Geringging Jaya.
\end{abstract}

Kata Kunci: model problem based learning, hasil belajar IPA

\begin{tabular}{|c|c|c|}
\hline Submitted & Accepted & Published \\
\hline 26 Juni 2019 & 2 November 2019 & 12 November 2019 \\
\hline
\end{tabular}

\begin{tabular}{|c|c|c|}
\hline Citation & $:$ & $\begin{array}{l}\text { Mariya. (2019). Keefektifan Model Problem Based Learning Untuk Meningkatkan Hasil Belajar IPA. Jurnal PAJAR } \\
\text { (Pendidikan dan Pengajaran), 3(6), 1247-1254. DOI : http://dx.doi.org/10.33578/pjr.v3i6.7883. }\end{array}$ \\
\hline
\end{tabular}

\section{PENDAHULUAN}

Ilmu Pengetahuan Alam (IPA) merupakan cara mencari tahu tentang alam secara sistematis, sehingga IPA tidak hanya diartikan sekumpulan pengetahuan yang berupa penguasaan konsep-konsep, fakta-fakta, atau prinsip-prinsip saja akan tetapi IPA juga merupakan proses penemuan (Suhendro dkk, 2016). Dengan mempelajari IPA akan memperoleh kumpulan informasi ilmiah dan pengetahuan tentang gejala-gejala yang ada di alam semesta.
Pembelajaran IPA bertujuan agar siswa dapat membangun sendiri pengetahuannya dengan cara memanfaatkan alam sekitar sebagai sumber belajarnya, sehingga siswa mampu berpikir kritis dan memiliki rasa ingin tahu yang tinggi untuk dapat memecahkan masalah secara ilmiah. Agar tercapainya tujuan pembelajaran IPA tidak terlepas dari peran seorang guru. Guru merupakan faktor terpenting yang akan menggerakkan proses pembelajaran, untuk itu guru dituntut harus lebih aktif dan kreatif dalam mengelola proses pembelajaran. 
Pembelajaran IPA sebenarnya tidaklah sulit untuk dipelajari namun kenyataannya pada saat pembelajaran IPA di SD Negeri 015 Geringging Jaya, banyak sekali masalah muncul yang dialami oleh guru, diantaranya: guru sering kesulitan dalam memunculkan minat belajar siswa, guru kurang optimal dalam penerapan metode pembelajaran yang ada, materi yang disajikan tidak diarahkan dalam dunia nyata/ kehidupan siswa akibatnya siswa tidak memiliki kebebasan bereksperimen dan berfikir secara kritis. Pembelajaran yang tidak bervariasi dan monoton membuat siswa kurang bersemangat dalam belajar, sehingga masalah ini berdampak pada rendahnya hasil belajar siswa (Kurniaman, \& Sismulyasih, 2019).

Sejalan dengan pendapat Ariyanto (2018) rendahnya hasil belajar IPA disebabkan peranan guru yang kurang maksimal di dalam proses pembelajaran. Hal ini terlihat dari guru masih menggunakan metode pembelajaran konvensional dengan metode ceramah sehingga saat proses pembelajaran terlihat beberapa siswa kurang antusias dan ada beberapa yang berbicara dengan temannya. lebih lanjut, (Muhammad, 2017) juga mengungkapkan rendahnya hasil belajar IPA siswa disebabkan oleh konsentrasi siswa yang kurang terfokus ketika proses pembelajaran berlangsung, selain itu tugas-tugas yang diberikan

\section{KAJIAN TEORETIS}

Problem based learning (PBL) adalah pembelajaran yang memiliki esensi berupa pemaparan berbagai situasi permasalahan yang autentik dan bermakna kepada siswa (Wulandari dkk, 2013). Lebih lanjut, Dewantara (2016) yang menyatakan bahwa PBL mampu mengubah proses pembelajaran menjadi student center sehingga siswa aktif, kritis dan mampu mengaitkan pembelajaran dengan kehidupan nyata siswa sehingga menjadikan pembelajaran yang lebih bermakna. PBL juga dapat mengoptimalkan tujuan, kebutuhan, motivasi yang mengarahkan suatu proses belajar yang merancang berbagai macam alternatif pemecahan masalah. Masalah dapat diartikan sebagai penyimpangan antara yang seharusnya dengan apa yang benar-benar terjadi antara teori dengan praktek, antara aturan dengan tidak dikerjakan dengan sungguh-sungguh oleh siswa. Siswa juga terlihat kurang semangat, acuh tak acuh dalam menghadapi pelajaran.

Untuk mengatasi masalah di atas diperlukan model yang tepat dalam proses pembelajaran agar siswa dapat berpikir kritis, kreatif, logis, serta bersikap ilmiah. Model yang akan digunakan dalam mengatasi permasalahan ini adalah problem based learning (PBL), dengan model PBL siswa selalu diajak berpikir untuk menghadapi masalah dunia nyata yang berhubungan erat dengan materi yang dipelajari. Hal ini sesuai dengan pendapat Isnaningsih dan Bimo (dalam Susanti, 2018) yang menyatakan pembelajaran IPA dapat dilakukan dengan membiasakan siswa bekerja secara ilmiah, sehingga dapat menumbuhkan kebiasaan berpikir dan bertindak yang merefleksikan penguasaan pengetahuan, keterampilan, dan sikap ilmiah selain itu dapat mengembangkan kemampuan memahami konsep- konsep IPA serta penerapannya dalam kehidupan sehari-hari adalah keterampilan proses.

Tujuan dilakukan penelitian ini adalah untuk meningkatkan hasil belajar IPA siswa kelas V SD Negeri 015 Geringging Jaya dengan menerapakan model pembelajaran problem based learning (PBL).

pelaksanaan, antara rencana dengan pelaksanaan (Sugiyono, 2013).

Hamdayama (2014) mengemukakan 6 karakteristik yang terdapat pada pembelajaran PBL, yaiyu: 1) Belajar dimulai dengan suatu masalah; 2) Memastikan bahwa masalah tersebut berhubungan dengan dunia nyata siswa; 3) Mengorganisasikan pelajaran seputar masalah; 4) Memberikan tanggung jawab yang besar kepada siswa dalam membentuk dan menjalankan secara langsung proses belajar mereka sendiri; 5) Menggunakan kelompok kecil, dan 6) Menuntut siswa mendemonstrasikan yang telah mereka pelajari dalam bentuk produk atau kinerja.

Kelebihan dari PBL adalah: 1) Peserta didik dapat belajar, mengingat, menerapkan, dan melanjutkan proses belajar secara mandiri. 
Prinsip-prinsip "membelajarkan" seperti ini tidak bisa dilayani melalui pembelajaran tradisional yang banyak menekankan pada kemampuan menghafal; 2) Peserta didik diperlakukan sebagai pribadi yang dewasa. Perlakuan ini memberikan kebebasan kepada peserta didik untuk mengimplementasikan pengetahuan atau pengalaman yang dimiliki untuk memecahkan masalah (Riyanto, 2010). Sedangkan manfaat dari menerapkan model PBL ini adalah: 1) Menjadi lebih ingat dan meningkat pemahamannya atas materi ajar; 2) Meningkatkan fokus pada pengetahuan yang relevan; 3) Mendorong untuk berpikir; 4) Membangun kerja tim, kepemimpinan, dan keterampilan sosial; 5) Membangun kecakapan belajar (life-long learning skill); dan 6) Memotivasi pemelajar.

PBL bukanlah suatu model yang sempurna karena juga mempunyai kelemahan. Adapun kelemahan dari model PBL ini adalah: 1) Tidak dapat diterapkan untuk setiap materi pelajaran, ada bagian guru berperan aktif dalam menyajikan materi serta; 2) Dalam suatu kelas yang memiliki tingat keragaman siswa yang tinggi akan terjadi kesulitan dalam pembagian tugas. Sedangkan sintaks dari model problem based learning menurut (Sumantri, 2015) adalah sebagai berikut

Tabel 1. Sintaks PBL

\begin{tabular}{ll}
\hline \multicolumn{1}{c}{ Tahap } & \multicolumn{1}{c}{ Aktivitas Guru } \\
\hline Tahap-1 & Guru menjelaskan tujuan pembelajaran, menjelaskan alat bahan \\
Orientasi siswa pada masalah & yang dibutuhkan, mengajukan fenomena atau demonstrasi atau \\
& cerita untuk memunculkan masalah, memotivasi siswa untuk \\
& terlibat dalam pemecahan masalah yang dipilih.
\end{tabular}

Tahap-2

Mengorganisasi siswa untuk belajar

Tahap-3

Membimbing penyelidikan individual maupun kelompok

Tahap-4

Mengembangkan dan menyajikan hasil karya

Tahap-5

Menganalisis dan mengevaluasi proses pemecahan masalah
Guru membantu siswa untuk mendefenisikan dan mengorganisasikan tugas belajar yang berhubungan dengan masalah tersebut.

Guru mendorong siswa untuk mengumpulkan informasi yang sesuai, melaksanakan eksperimen untuk mendapatkan penjelasan dan pemecahan masalah.

Guru membantu siswa dalam merencanakan dan menyiapkan karya yang sesuai seperti laporan, video, dan model serta membantu mereka untuk berbagi tugas dengan temannya.

Guru membantu siswa untuk melakukan refleksi atau evaluasi terhadap penyelidikan mereka dan proses-proses yang mereka gunakan.

\section{METODE PENELITIAN}

Penelitian ini dilakukan di kelas V SD Negeri 015 Geringging Jaya, Kecamatan Sentajo Raya, Kabupaten Kuantan Singingi, Provinsi Riau, Indonesia. Subjek pada penelitia ini adalah siswa kelas V SD Negeri 015 Geringging Jaya yang berjumlah 18 orang siswa, terdiri dari 8 orang siswa laki-laki dan 10 orang siswa perempuan dengan kemampuan yang heterogen.

Bentuk penelitian yang dilakukan adalah penelitian tindakan kelas (PTK). Penelitian tindakan kelas secara garis besar terdapat empat tahap yang biasa dilalui yaitu: perencanaan, pelaksanaan, pengamatan, dan refleksi (Yudhistira, 2013). Uraian dan penjelasan untuk masing-masing tahap adalah sebagai berikut: 1) Perencanaan Tindakan, dalam tahap perencanaan ini yang perlu dilakukan adalah menyusun rangkaian pelaksanaan pembelajaran berupa silabus, RPP, LKS, mempersiapkan tes hasil belajar dan membuat lembaran pengamatan aktivitas guru dan aktivitas siswa; 2) Pelaksanaan tindakan, pada tahap kedua dari penelitian tindakan ini adalah pelaksanaan yang merupakan penerapan isi rancangan. Melakukan 
pembelajaran di kelas dengan penerapan model pembelajaran problem based learning; 3) Pengamatan, pada tahap pengamatan dilakukan bersamaan dengan pelaksanaan tindakan, observasi dilakukan peneliti dan guru sebagai observer dengan menggunakan lembar pengamatan; 4) Refleksi dilakukan setelah tindakan berakhir yang merupakan mengkaji, melihat, dan mempertimbangkan atas hasil atau dampak dari tindakan, kelemahan, dan kekurangan dalam pembelajaran yang menerapkan model pembelajaran problem based learning.

Hasil dari data yang peneliti peroleh dianalisis untuk memperoleh gambaran tentang aktivitas guru dan aktifitas siswa dalam proses belajar mengajar, serta hasil belajar siswa. adapun uraiannya dapat dilihat sebagai berikut:

\section{Analisis Data Aktivitas Guru dan Siswa}

Setelah data terkumpul maka dicari persentase pada tiap pertemuan dan masingmasing siklus dengan menggunakan rumus sebagai berikut:

$$
\mathrm{NP}=\frac{R}{S M} X 100 \% \quad \text { (Purwanto, 2009) }
$$

Keterangan:

$$
\begin{aligned}
\mathrm{NP}= & \text { persentase rata-rata aktivitas } \\
& \text { guru/siswa } \\
\mathrm{R}= & \text { jumlah skor aktivitas yang dilakukan } \\
\mathrm{SM}= & \begin{array}{c}
\text { skor maksimal yang didapat dari } \\
\text { aktivitas guru/siswa }
\end{array}
\end{aligned}
$$

Kategori penilaian aktivitas guru dan siswa tersebut dapat dilihat pada tabel berikut ini:

Tabel 2. Kategori Aktivitas Guru dan Siswa

\begin{tabular}{ll}
\hline Interval & Kategori \\
\hline $86-100$ & Amat baik \\
$76-85$ & Baik \\
$60-75$ & Cukup \\
$55-59$ & Kurang \\
$\leq 54$ & Kurang sekali \\
\hline
\end{tabular}

\section{Ketuntasan Hasil Belajar}

a) Ketuntasan hasil belajar individu

Dalam penelitian ini setiap siswa dikatakan tuntas apabila mendapat nilai minimal 70 berdasarkan KKM yang telah ditetapkan oleh sekolah dengan menggunakan rumus:

$$
\mathrm{S}=\frac{R}{N} X 100 \quad \text { (Purwanto, 2009:112) }
$$

Keterangan:

$\mathrm{S}=$ nilai yang diharapkan (dicari)

$\mathrm{R}=$ jumlah skor dan item atau soal yang dijawab benar

\section{HASIL DAN PEMBAHASAN}

Analisis hasil tindakan diolah berdasarkan teknik analisis data yang dijelaskan pada metode penelitian sebelumnya. Data yang
$\mathrm{N}=$ skor maksimum dari tes tersebut

b) Ketuntasan Klasikal

Untuk mengetahui ketuntasan klasikal digunakan rumus sebagai berikut:

$$
\mathrm{KB}=\frac{T}{T t} X 100 \% \quad \text { (Trianto, 2009) }
$$

Keterangan:

$\mathrm{KB}=$ ketuntasan belajar

$\mathrm{T}=$ jumlah skor yang diperoleh siswa

$\mathrm{Tt} \quad=$ jumlah skor total

dikumpulkan merupakan data tentang aktivitas guru dan siswa serta data hasil belajar siswa. Hasil tindakan yang akan dianalisis yaitu data 
aktivitas guru dan siswa selama proses pembelajaran IPA berlangsung. Data diperoleh dari lembar observasi aktivitas guru dan siswa setiap kali pertemuan, serta data hasil belajar siswa yang diperoleh dari hasil ulangan harian siswa setiap siklus.

Aktivitas guru

Observasi aktivitas guru dilaksanakan bersamaan dengan pelaksanaan kegiatan proses pembelajaran yang dilakukan menggunakan model problem based learning (PBL). Data hasil observasi tentang aktivitas guru selama proses pembelajaran pada setiap pertemuan siklus I dan siklus II yang dilakukan oleh observer dari awal hingga akhir pembelajaran disetiap pertemuan dapat dilihat pada tabel rekapitulasi aktivitas guru di bawah ini:

Tabel 3. Rekapitulasi Skor Aktivitas Guru Siklus I dan Siklus II

\begin{tabular}{|c|c|c|c|c|}
\hline \multirow{2}{*}{ Aspek Penilaian } & \multicolumn{2}{|c|}{ Siklus I } & \multicolumn{2}{|c|}{ Sikus II } \\
\hline & P1 & P2 & P1 & $\mathbf{P 2}$ \\
\hline Skor Penilaian & 16 & 18 & 22 & 23 \\
\hline Persentase Penilaian & $64 \%$ & $72 \%$ & $88 \%$ & $92 \%$ \\
\hline Kategori Penilaian & Cukup & Baik & Amat Baik & Amat baik \\
\hline
\end{tabular}

Berdasarkan tabel rekapitulasi penilaian aktivitas guru di atas dapat dilihat adanya peningkatan aktivitas guru selama empat kali pertemuan dalam dua siklus penerapan model problem based learning. Pertemuan pertama siklus I persentase aktivitas guru tergolong dalam kategori cukup dengan skor penilaian aktivitas sebesar 16 dengan persentase sebesar 64\%. Pada pertemuan kedua siklus I kategori aktivitas guru berkategori baik dengan skor penilaian aktivitas sebesar 18 dengan persentase sebesar $72 \%$. Pada siklus II pertemuan pertama kategori aktivitas guru tergolong dalam kondisi amat baik sehingga jumlah skor penilaian dan persentase meningkat dari petemuan sebelumnya, yaitu dengan jumlah skor penilaian sebesar 22 dengan persentase sebesar $88 \%$. Untuk aktivitas guru pada pertemuan kedua siklus II juga tergolong amat baik dengan jumlah skor aktivitas sebesar 23 dengan persentase sebesar $92 \%$.

Pada pertemuan pertama guru mengalami banyak kesulitan baik dalam mengelola kelas, mengelola waktu, memotivasi siswa, serta masih terlihatnya siswa yang meribut dan menggangu sisa lain sehingga keadaan kelas menjadi kurang kondusif, serta berdampak pada saat melakukan eksperimen guru tidak maksimal dalam membimbing penyelidikan kelompok. Pada pertemuan ke dua siklus I, permasalahan dan kesulitan masih dialami guru walaupun hasil penilaian skor aktivitas meningkat. Permasalahan yang ditemukan adalah guru dalam memotivasi siswa belum terlalu berpengaruh terhadap minat dan antusias belajar siswa, serta keadaan kelas yang masih sulit dikontrol membuat pengelolaan waktu belum berjalan dengan baik. Pada pertemuan pertama siklus II, guru sudah mulai bisa mengontrol kelas dan mengatasi masalahmasalah yang muncul dalam proses pembelajaran. Sedangkan pada pertemuan ke dua siklus II, guru sudah bisa dan terbiasa dalam mengatasi masalah kelas, bahkan guru sudah dapat mengontrol kelas dan memotivasi siswa dengan baik. Setiap pertemuan terjadi peningkatan karena guru selalu mengevaluasi aktivitas guru dan melaksanakan masukan yang diberikan observer disetiap pertemuan.

\begin{abstract}
Aktivitas Siswa
Aktivitas siswa selama mengikuti proses pembelajaran juga diamati oleh observer dengan menggunakan lembar observasi aktivitas siswa dari awal sampai akhir pembelajaran. Dari hasil observasi tentang aktivitas belajar siswa pada setiap pertemuan dan siklus dapat dilihat pada tabel rekapitulasi aktivitas siswa di bawah ini:
\end{abstract}


Tabel 4. Rekapitulasi Skor Aktivitas Siswa Siklus I dan Siklus II

\begin{tabular}{|c|c|c|c|c|}
\hline \multirow{2}{*}{ Aspek Penilaian } & \multicolumn{2}{|c|}{ Siklus I } & \multicolumn{2}{|c|}{ Sikus II } \\
\hline & $\mathbf{P 1}$ & $\mathbf{P 2}$ & $\mathbf{P 1}$ & $\mathbf{P 2}$ \\
\hline Skor Penilaian & 15 & 19 & 21 & 24 \\
\hline Persentase Penilaian & $60 \%$ & $76 \%$ & $84 \%$ & $96 \%$ \\
\hline Kategori Penilaian & Cukup & Baik & Baik & Amat baik \\
\hline
\end{tabular}

Berdasarkan tabel rekapitulasi penilaian aktivitas siswa di atas sama halnya dengan aktivitas guru yang mengalami peningkatan setiap pertemuannya. Pertemuan pertama siklus I persentase aktivitas siswa tergolong dalam kategori cukup dengan skor penilaian aktivitas sebesar 15 dengan persentase sebesar 60\%. Pada pertemuan kedua siklus I kategori aktivitas siswa dalam kategori baik dengan skor penilaian aktivitas sebesar 19 dengan persentase sebesar $76 \%$. Pada siklus II pertemuan pertama kategori aktivitas siswa masih tergolong dalam kondisi baik namun jumlah skor penilaian dan persentase meningkat dari petemuan sebelumnya, yaitu dengan jumlah skor penilaian sebesar 21 dengan persentase sebesar $84 \%$. Untuk aktivitas siswa pada pertemuan kedua siklus II tergolong amat baik dengan jumlah skor aktivitas sebesar 24 dengan persentase sebesar $96 \%$.

Pada pertemuan pertama siklus I, siswa masih sulit dikontrol dan belum termotivasi untuk mengikuti kegiatan pembelajaran. Siswa lebih banyak bermain dan mengganggu teman atau kelompok lainnya. Pada perteuan kedua siklus I, siswa sudah mulai menunjukan kerja sama dengan anggota kelompok, namun masih saja terlihat yang bercanda atau tidak serius dalam malkukan pembelajaran. terlihat siswa juga masih belum percaya diri untuk tampil dan mengutarakan pendapat ketika guru memberikan pertanyaan. Pada pertemuan kesau siklus II, terlihat siswa sudah mulai bisa dikontrol dan percaya diri siswa mulai timbul dan siswa terlihat serius dalam melaksanakan pembelajaran. Pada pertemuan terakhir siklus II, siswa lebih aktif dari pertemuan sebelumnya, siswa tampak antusias melakukan pembelajaran serta lebih percaya diri serta mampu berpikir secara kritis. Peningkatan ini terjadi karena siswa telah memahami dan melaksanakan langkah-langkah model problem based learning secara tepat.

\section{Hasil Belajar Siswa}

Data peningkatan hasil belajar diperoleh setelah melaksanakan UH I dan UH II. Peningkatan hasil belajar siswa dapat dilihat dari nilai-nilai kelas siswa. Data peningkatan hasil belajar siswa dengan penerapan model problem based learning pada kelas V SD Negeri 015 Geringging Jaya dapat dilihat pada tabel di bawah ini:

Tabel 5. Hasil Belajar Siswa

\begin{tabular}{|c|c|c|c|c|c|}
\hline \multirow{3}{*}{ Tahap } & \multirow{3}{*}{$\begin{array}{c}\text { Jumlah } \\
\text { Siswa }\end{array}$} & \multicolumn{3}{|c|}{ Ketuntasan Hasil Belajar } & \multirow{3}{*}{ Ket } \\
\hline & & \multicolumn{2}{|c|}{ Individual } & \multirow{2}{*}{$\begin{array}{c}\text { Rata-rata } \\
\text { Kelas }\end{array}$} & \\
\hline & & Tuntas & Tidak Tuntas & & \\
\hline Data awal & 18 & $10(55.5 \%)$ & $8(44.5 \%)$ & 63.2 & Tidak Tuntas \\
\hline Siklus I & 18 & $14(77.7 \%)$ & $4(22.3 \%)$ & 74.3 & Tuntas \\
\hline Siklus II & 18 & $16(88.8 \%)$ & $2(11,2 \%)$ & 86.7 & Tuntas \\
\hline
\end{tabular}

Berdasarkan data analisis tabel 5 di atas, dapat dilihat bahwa adanya peningkatan dari hasil belajar siswa setelah diterapkan model problem based learning. Nilai rata-rata skor dasar siswa adalah 63.2 dengan siswa yang tuntas sebanyak 10 orang dengan persentase sebesar $55.5 \%$ mengalami peningkatan pada siklus I dengan nilai rata-rata siswa menjadi 74.3 dengan siswa yang 
tuntas menjadi 14 orang dengan persentase sebesar $77.7 \%$. Sedangkan pada siklus II kembali menngkata dengan nilai rata-rata sebesar 86.7 dengan siswa yang tuntas menjadi 16 orang dengan persentase sebesar $88.8 \%$. Peningkatan hasil belajar ini terjadi karena siswa mampu mengembangkan komunikasi, kerjasama, dalam asfek koknitif, afektif dan psikomotorik siswa dengan bantuan model problem based learning yang dilakukan guru dalam proses pembelajaran.

Peningkatan hasil belajar ini sejalan dengan pendapat Nafiah (2014) yang menyatakan melalui PBL siswa dibekali pengalaman dalam menangani masalah-masalah yang realistis, dan menekanan pada penggunaan komunikasi, kerjasama, dan sumber-sumber yang ada untuk merumuskan ide dan mengembangkan keterampilan penalaran.

\section{Pembahasan}

Data aktivitas guru dan aktivitas siswa di atas menunjukkan perkembangan yang signifikan ke arah yang lebih baik. Pelaksanaan tahapantahapan dalam model problem based learning yang sesuai dengan perencanaan berdampak pada semakin baiknya proses belajar mengajar. Model PBL yang menuntut student-center menjadikan

\section{SIMPULAN DAN REKOMENDASI}

Berdasarkan data hasil penelitian di atas dengan menerapkan model problem based learning dapat peneliti simpulkan bahwa penerapan model problem based learning efektif meningkatkan hasil belajar IPA siswa kelas V SD Negeri 015 Geringging Jaya Kecamtan Sentajo Raya. Peningkatan hasil belajar dapat dilihat sebagai berikut: 1) Aktivitas guru, pertemuan pertama siklus I skor penilaian aktivitas sebesar 16 dengan persentase sebesar 64\%. Pada pertemuan kedua meningkat menjadi 18 dengan persentase sebesar $72 \%$. Pada siklus II pertemuan pertama skor penilaian sebesar 22 dengan persentase sebesar $88 \%$. pertemuan kedua siklus II kembali meningkat menjadi 23 dengan persentase sebesar 92\%; 2) Aktivitas Siswa, pertemuan pertama siklus I skor penilaian aktivitas sebesar 15 dengan persentase sebesar $60 \%$. Pada pertemuan kedua skor penilaian siswa mulai bisa membangun sendiri pengetahuannya dan lebih mandiri dalam proses belajar sehingga guru pun dapat menjalankan tugas yang sesungguhnya dengan baik yaitu sebagai fasilitator dengan selalu memberi stimulus motivasi selayaknya motivator dan tutor.

PBL yang dikemukakan oleh Sanjaya (2010) yaitu "Pemecahan masalah (problem solving) dapat meningkatkan aktivitas dan hasil pembelajaran siswa". Hal ini sesuai dengan pendapat Vygotsky (dalam Dahar, 2006) yang mengatakan bahwa interaksi sosial itu penting saat siswa menginternalisasi pemahamanpemahaman yang sulit, masalah-masalah, dan proses. Selanjutnya proses internalisasi melibatkan rekonstruksi aktivitas psikologis dengan dasar penggunaan bahasa. Jelas tampak bahwa penggunaan bahasa secara aktif yang didasarkan pemikiran merupakan sarana bagi para siswa untuk menegosiasi kebermaknaan pengalaman-pengalaman. Pembelajaran bermakna akan berdampak pada penyimpanan pembelajaran yang lebih lama karena pengetahuan yang didapat siswa dekat dengan kegiatan sehari-hari dan siswa mengalami langsung setiap tahapan yang terjadi.

meningkat menjadi 19 dengan persentase sebesar 76\%. Pada siklus II pertemuan pertama skor penilaian sebesar 21 dengan persentase sebesar 84\%. Pertemuan kedua siklus II kembali meningkat menjadi 24 dengan persentase sebesar 96\%; 3) Hasil Belajar Siswa, dilihat dari nilai rata-rata skor dasar siswa adalah 63.2 dengan siswa yang tuntas sebanyak 10 orang dengan persentase sebesar $55.5 \%$ mengalami peningkatan pada siklus I dengan nilai rata-rata siswa menjadi 74.3 dengan siswa yang tuntas menjadi 14 orang dengan persentase sebesar $77.7 \%$. Sedangkan pada siklus II kembali menngkata dengan nilai rata-rata sebesar 86.7 dengan siswa yang tuntas menjadi 16 orang dengan persentase sebesar $88.8 \%$.

Berdasarkan hasil penelitian di atas dapat peneliti rekomendasikan hal-hal sebagai berikut:

1. Untuk guru yang akan menerapkan model 
problem based learning, hendaknya memahami terlebih dahulu dengan baik langkah-langkah PBL agar tujuan pembelajaran tercapai secara maksimal. Selain itu guru dituntut kreatif dalam mempersiapkan eksperimen yang akan menjadi solusi dalam pemecahan masalah sebagai stimulus

\section{DAFTAR PUSTAKA}

Dahar, R.W. (2006). Teori-teori Belajar dan Pembelajaran. Bandung: Erlangga.

Dewantara, D. (2016). Penerapan Model Pembelajaran Problem Based Learning untuk Meningkatkan Aktivitas dan Hasil Belajar Siswa Pada Pelajaran IPA (Studi Pada Siswa Kelas V SDN Pengambangan 6 Banjarmasin). Jurnal Pradigma, 11(2), 4144.

Hamdayama, J. (2014). Model dan Metode Pembelajaran Kreatif dan Berkarakter. Jakarta: Ghalia Indonesia.

Hariyanto, M. (2016). Peningkatan Hasil Belajar Ipa Materi Kenampakan Rupa Bumi Menggunakan Model Scramble. Profesi Pendidikan Dasar, 3(2), 134 - 140.

Kurniaman, O., \& SB. Sismulyasih, N. (2019). The Influence of The Big Book Media Has The Character of Conservation in Early Reading. ELS Journal on Interdisciplinary Studies in Humanities, 2(1), 141-147.

Muhammad, M. H. (2017). Penerapan Metode Pemberian Tugas untuk Meningkatkan Hasil Belajar IPA Siswa Kelas IV SD Negeri 004 Tembilahan Kecamatan Tembilahan Kabupaten Indragiri Hilir. Primary: Jurnal Program Studi Pendidikan Guru Sekolah Dasar, 6(1), 242-251.

Nafiah, Y.N. (2014). Penerapan Model ProblemBased Learning untuk Meningkatkan Keterampilan Berpikir Kritis dan Hasil Belajar Siswa. Jurnal Pendidikan Vokasi, 4(1), 125-143.

Purwanto, N. (2014). Evaluasi Hasil Belajar. Surakarta: Pustaka Pelajar.

Riyanto, Y. (2010). Paradigma Baru Pembelajaran Sebagai Referensi Bagi Guru/Pendidik dalam Implementasi Pembelajaran yang Efektif dan pembelajaran yang mendorong siswa menggunakan pengetahuannya.

2. Bagi peneliti berikutnya dapat dijadikan sebagai referensi untuk melakukan penelitian yang berhubungan dengan model problem based learning.

Berkualitas. Jakarta: Kencana Prenada Media Group.

Suhendro., Sarjan, N., Husain., \& Djirimu, M. (2016). Meningkatkan Hasil Belajar Siswa Pada Mata Pelajaran IPA (Bagian-Bagian Tumbuhan) Dengan Pemanfaatan Lingkungan Alam Sekitar Kelas IV SDK Padat Karya. Jurnal Kreatif Tadulako Online, 4(5), 118-130.

Susanti, P.D.A. (2018). Peningkatan Hasil Belajar IPA Melalui Penerapan Model Pembelajaran Berbasis Masalah (Problem Based Learning) Pada Siswa Kelas V SDN Purwasari III Kabupaten Karawang. Prosiding Seminar dan Diskusi Nasional Pendidikan Dasar 2018.

Sugiyono. (2013). Metode Penelitian Pendidikan. Bandung: Alfabeta.

Sumantri, M.S. (2015). Strategi Pembelajaran Teori dan Praktik di Tingkat Pendidikan Dasar. Jakarta: Rajawali Pers.

Trianto. (2009). Mendesain Model Pembelajaran Inovatif-Progresif. Surabaya: Kencana.

Sanjaya, W. (2010). Strategi Pembelajaran Berorientasi Standar Proses Pendidikan. Jakarta: Prenada Media Grup.

Wulandari, B., \& Sujono, H.D. (2013). Pengaruh Problem-Based Learning Terhadap Hasil Belajar Ditinjau Dari Motivasi Belajar PLC Di SMK. Jurnal Pendidikan Vokasi, 3(2), 178-191.

Yudhistira, D. (2012). Menulis Penelitian Tindakan Kelas yang APIK (Asli Perlu Ilmiah Konsisten). Tasikmalaya: Grasindo. 